\title{
Pengaruh Kompensasi Dan Stres Kerja Terhadap Turnover Intention Karyawan Bagian Cutting Pada PT. Kwangduk World Wide Cikalong Wetan
}

\author{
Novi Rukhviyanti ${ }^{1}$, Santi Susanti ${ }^{2}$ \\ Program Studi Manajemen ${ }^{1,2}$
}

STIE STAN Indonesia Mandiri, Jl. Jakarta No.79 Bandung ${ }^{1,2}$

Email : novi.rukhviyanti@stmik-im.ac.id ${ }^{1}$, santisusanti6916@gmail.com²

\begin{abstract}
ABSTRAK
Penelitian ini bertujuan untuk mengetahui Pengaruh Kompensasi dan Stres Kerja Terhadap Turnover Intention pada karyawan PT Kwangduk World Wide bagian Cutting.

Jumlah sampel yang digunakan sebanyak 88 responden dengan menggunakan teknik Purposive Sampling. Metode penelitian Explanatory Survey, Deskriptif dan Verifikatif/Asosiatif, teknik pengumpulan data melalui penyebaran Kuesioner. Hipotesisnya diuji dengan analisa Uji Validitas, Uji Reliabilitas, Uji T, Koefisien Korelasi dan Uji Regresi Linier Berganda.

Hasil penelitian ini menunjukan bahwa secara parsial, variabel Kompensasi mempunyai pengaruh yang negatif dan signifikan terhadap variabel turnover intention dan Variabel Stres Kerja juga mempunyai pengaruh yang positif dan signifikan terhadap variabel turnover intention.
\end{abstract}

Kata Kunci : Kompensasi, Stres Kerja, dan Turnover Intention

\section{ABSTRACT}

This study aims to determine the Effect of Compensation and Job Stress Against Turnover Intention on the employees of PT Kwangduk World Wide Cutting section. The number of samples used was 88 respondents using purposive sampling technique. Explanatory Survey research methods, Descriptive and Verificative / Associative, data collection techniques through questionnaires. The hypothesis is tested by analyzing the Validity Test, Reliability Test, T Test, Correlation Coefficient and Multiple Linear Regression Tests.

The results of this study indicate that partially, the Compensation variable has a negative and significant effect on the variable turnover intention and the Work Stress Variable also has a positive and significant effect on the variable turnover intention.

Keywords: Compensation, Job Stress, and Turnover Intention

\section{PENDAHULUAN}

Persaingan dalam dunia bisnis di era globalisasi sekarang ini semakin ketat, sehingga perusahaan harus dapat memiliki sutu keunggulan dan kemampuan daya saing yang tinggi, agar dapat bertahan dan bersaing dengan perusahaan lainnya. Memiliki keunggulan dan daya saing yang tinggi tentunya diperlukan sumber daya yang 
baik.Sumber daya manusia (SDM) merupakan aset terpenting dalam sebuah organisasi. Oleh karena itu SDM adalah asset yang tak ternilai keberadaannya bagi satu perusahan sehingga harus di pertahankan dan dihindari terjadinya turnover (perpindahan).

Robbin (2006) turnover adalah pemberhentian pegawai yang bersifat permanen dari perusahaan baik yang dilakukan pegawai sendiri (secara sukarela) maupun yang dilakukan oleh perusahaan. Fenomena turnover ini juga dialami oleh PT. Kwangduk World Wide, hasil wawancara penulis berasumsi bahwa tingkat turnover pada PT. Kwangduk World wide dapat di kategorikan tinggi karena melakukan perekrutan karyawan baru setiap minggunya. Fenomena ini secara tidak langsung masuk kedalam masalah hal dalam penanganan stress sehingga perusahan tidak dapat memprediksikan sikap karyawan tersebut. Stres bisa membuat ketidakpuasan kerja (job dissatisfaction), meningkatnya turnover, dan kehilangan tenaga kerja (Nugroho 2008). Syahronica \& Ruhana (2015) stress merupakan factor domain yang mempengaruhi turnover intention. Klassen (2011) mengemukakan stress kerja mempunyai pengaruh positif dengan turnover intention, stess kerja yang dihadapi pegawai secara berlebihan berimplikasi terhadap turnover intention.

Perusahaan menginginkan karyawannya produktif dalam bekerja dan setia kepada perusahaan. Upaya perusahaan untuk mewujudkan hal tersebut adalah dengan memberikan kompensasi kepada karyawan. Kompensasi merupakan sesuatu yang diterima karyawan sebagai pengganti kontribusi jasa mereka pada perusahaan (rivai, 2004; 357). Menurut Hasibuan (2012) Kompensasi adalah semua pendapatan yang berbentuk uang, barang langsung atau tidak langsung yang diterima karyawan sebagai imbalan atas jasa yang diberikan kepada perusahaan. Kompensasi dibedakan menjadi dua, yaitu: Kompensasi langsung yaitu berupa gaji, upah dan insentif; dan kompensasi tidak langsung berupa asuransi, tunjangan, cuti, penghargaan. Fungsi dari kompensasi yang diberikan diharapkan akan meningkatkan kepuasan kerja, pengadaan yang efektif, memotivasi, menjaga stabilitas karyawan, menjaga kedisiplinan, penghindaran serikat buruh, dan pengaruh intervensi pemerintah (Ardana, dkk., 2012:154).

Pemberian kompensasi yang baik oleh perusahaan dinilai efektif untuk meningkatkan kesetiaan karyawan terhadap perusahaan. Hal itu akan mengurangi keinginan 
untuk berpindah pekerjaan (Turnover intention) karyawan yang bekerja pada perusahaan, sehingga turnover karyawan bisa ditekan dan biaya perekrutan karyawan dapat berkurang. Jika kompensasi yang tidak memuaskan terhadap hasil kerja baik secara finansial maupun non finansial dan perusahaan tidak bisa memberikan hal yang dituntut oleh karyawan maka karyawan cenderung memilih untuk mengundurkan diri dari perusahaan dan mencari lapangan pekerjaan lain diluar sana yang menawarkan pemberian kompensasi yang lebih besar.

Beberapa penelitian sebelumnya yang dilakukan oleh K. Ayu Budiastiti Purnama Dewi (2016) menyatakan bahwa stress kerja berpengaruh langsung secara positif pada turnover intention agen AJB Bumiputera 1912 Cabang Renon Denpasar, stress kerja berpengaruh negative pada kepuasan kerja agen AJB Bumiputera 1912 Cabang Renon Denpasar dan kepuasan kerja berpengaruh negative pada turnover intention agen AJB Bumiputera 1912 Cabang Renen Denpasar.

Berbeda dengan hasil penelitian dari Wulansari et al (2017), Hasil penelitian menunjukkan bahwa keadilan prosedural berpengaruh positif terhadap komitmen organisasi, kemudian stres kerja berpengaruh positif terhadap komitmen organisasi, selain itu keadilan prosedural tidak berpengaruh terhadap intensi turnover, kemudian stres kerja tidak berpengaruh terhadap intensi turnover, dan komitmen organisasional tidak berpengaruh terhadap komitmen turnover.

Asmara Hendra Komara dan Novi Erika (2017) menyatakan bahwa melalui uji validitas, realibilitas dan uji asumsi klasik di ketahui adanya pengaruh yang signifikan dari kompensasi dan stress kerja terhadap intensi turnover karyawan di PT. Dwiwira Putra Dinamika sedangkan variable promosi jabatan tidak berpengaruh secara parsial.

Bertolak belakang dengan hasil penelitian yang dilakukan oleh Catur Widayanti dan Yolanda Yunia (2016) menyatakan bahwa secara parsial, variable kompensasi mempunyai pengaruh negative dan signifikan terhadap variable turnover intention. Variable budaya organisasi mempunyai pengaruh negative dan signifikan terhadap variable turnover intention. 


\section{Identifikasi Masalah}

Dari beberapa uraian yang dikemukakan pada latar belakang, maka dapat diidentifikasi masalah-masalah sebagai berikut :

1. Bagaimana Kompensasi, Stres Kerja dan Turnover Intention menurut persepsi karyawan di PT. Kwangduk World Wide?

2. Apakah kompensasi secara parsial berpengaruh negatif dan signifikan terhadap turnover intention?

3. Apakah stress kerja secara parsial berpengaruh positif dan signifikan terhadap turnover intention?

\section{METODE PENELITIAN}

\subsection{Review Literatur dan Hipotesis}

\subsubsection{Kompensasi}

Menurut simamora (2006:514) Kompensasi adalah bayaran yang diberikan perusahaan untuk dapat meningkatkan produktivitas para karyawan guna mencapai keunggulan yang kompetitif. Kemudian menurut Sastrohadiwiryo dalam Yuniarsih (2011:125), menyatakan bahwa "Kompensasi adalah imbalan jasa atau balas jasa yang diberikan oleh perusahaan kepada tenaga kerja, karena para tenaga kerja tersebut telah memberikan sumbangan tenaga dan pikiran demi kemajuan perusahaan guna mencapai tujuan yang ditetapkan".

Sedangkan menurut Hasibuan (2013: 117) Kompensasi adalah semua pendapatan yang berbentuk uang, barang langsung atau tidak langsung yang diterima pegawai sebagai imbalan atas jasa yang diberikan perusahaan. Kompensasi di bedakan menjadi dua, yaitu: kompensasi langsung yaitu berupa gaji, upah, insentif, dan kompensasi tidak langsung berupa asuransi, tunjangan, cuti, penghargaan. Istilah kompensasi mengacu kepada semua bentuk balas jasa uang dan semua barang atau komoditas yang digunakan sebagai balas jasa uang kepada karyawan (daft, 2000:536).

\subsubsection{Stess Kerja}

Menurut Robbins (2008) stress adalah suatu kondisi dinamik yang didalamnya seorang individu di konfrotasikan dengan suatu peluang, kendala, atau tuntutan yang dikaitkan dengan apa yang sangat diinginkan dan hasilnya di persepsikan sebagai tidak pasti dan penting. 
Stres sebagai suatu istilah paying yang merangkumi tekanan, beban, konflik, keletihan, ketegangan, panik, perasaan gemuruh, kemurungan dan hilang daya. Stress kerja adalah suatu kondisi ketegangan yang menciptakan adanya ketidakseimbangan fisik dan psikis, yang mempengaruhi emosi, proses berpikir, dan kondisi seorang karyawan (Rivai, 2009:724). Menurut (Rivai, 2011:516) menyatakan bahwa "Stres yang terlalu besar dapat mengancam kemampuan seseorang untuk menghadapi lingkungan. Sebagai hasilnya, pada diri para pegawai berkembang berbagai macam gejala stres yang dapat mengganggu pelaksanaan kerja mereka".

\subsubsection{Turnover Intention}

Mobley (2011:15), menyatakan bahwa "Turnover intention adalah hasil evaluasi individu mengenai kelanjutan hubungannya dengan perusahaan dimana dia bekerja namun belum diwujudkan dalam tindakan nyata. Hartono (2002):2) dalam sianipar dan haryanti (2014) "turnover interntion adalah kadar atau intensitas dari keinginan untuk keluar dari perusahaan, banyak alasan yang menyebabkan timbulnya turnover interntion ini dan diantaranya adalah untuk mendapatkan pekerjaan yang lebih baik".

\subsubsection{Hubungan Kompensasi dengan Turnover Intention}

Bibowo, Adi dan Mspudi, Erni (2015) menunjukkan bahwa kompensasi dan pengembangan karir positif dan signifikan mempengaruhi kepuasan. Selanjutnya kompensasi, pengembangan karir dan kepuasan pekerjaan bersama-sama memiliki pengaruh yang signifikan terhadap turnover intention. Tapi secara parsial hanya kepuasan kerja yang memiliki pengaruh yang signifikan negative untuk omset niat. Catur Widyati dan Yolanda Yunia (2016) hasil penelitiannya adalah secara parsil variabel kompensasi mempunyai pengaruh yang negatif dan signifikan terhadap variabel turnover intention. Variabel budaya organisasi mempunyai pengaruh yang negatif dan signifikan terhadap variabel turnover intention. Irabayuni, Sulastri (2012) bahwa menjunjukkan kompensasi berpengaruh tidak signifikan terhadap Keinginan untuk pindah kerja karyawan, Kepuasan kerja berpengaruh positif dan tidak signifikan terhadap keinginan untuk pindah kerja karyawan, dan komitmen organisasi berpengaruh negatif dan signifikan terhadap keinginan untuk pindah kerja karyawan. 


\subsubsection{Hubungan Stress Kerja dengan Turnover Intention}

Yuliana Ayu Wulansari, Teman Koesmoro dan Marliana Junaedi (2017), bahwa menunjukkan keadilanprosedural berpengaruh positif terhadap komitmen organisasi, kemudian stress kerja berpengaruh positif terhadap komitmen organisasi, selain itu keadilan prosedural tidak berpengaruh terhadap intensi turnover, kemudian stres kerja tidak berpengaruh terhadap intensi turnover. Dan komitmen organisasi tidak berpengaruh terhadap komitmen turnover pada niat turnover.

\subsection{Model Analisis}

Berdasarkan penjelasan diatas, dapat digambarkan kerangka pemikiran mengenai hubungan antara variable independen yaitu Kompensasi dan Stres Kerja serta Variabel dependen yaitu Turnover Intention

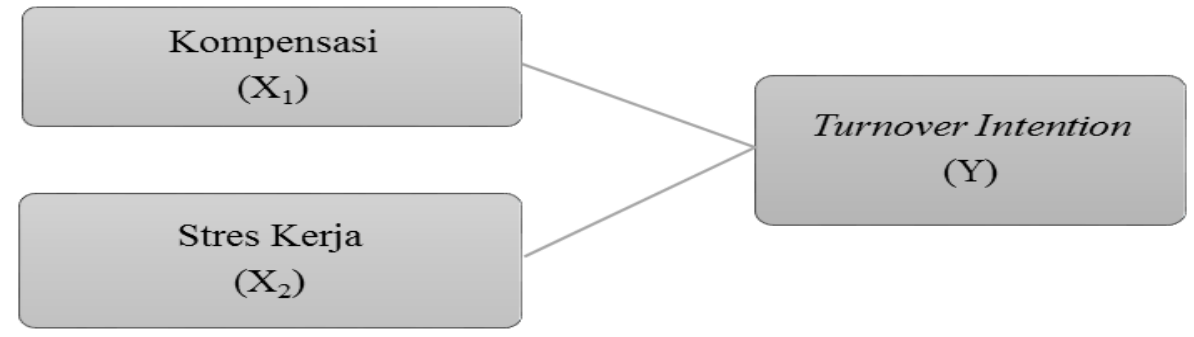

Gambar 1: Model Hipotesis

\subsection{HIPOTESIS}

Berdasarkan uraian kerangka pemikiran di atas, maka penulis merumuskan hipotesis sebagai berikut:

$\mathrm{H}_{1} \quad$ : Kompensasi (X1) berpengaruh negatif dan signifikan terhadap Turnover Intention (Y).

$\mathrm{H}_{2}$ : Stres Kerja (X2) berpengaruh positif dan signifikan terhadap Turnover Intention $(\mathrm{Y})$.

Sample yang diambil dalam penelitian berjumlah 88 orang di PT. Kwangduk Worl Wide, Cikalong Wetan. dengan menggunakan teknik Purposive Sampling. Metode penelitian Explanatory Survey, Deskriptif dan Verifikatif/Asosiatif, Menurut sugiyono (2013:7) "Metode deskriptif adalah penelitian yang dilakukan untuk 
mengetahui variabel mandiri, baik satu variabel atau lebih (variabel yang berdiri sendiri) tanpa membuat perbandingan atau menghubungkan antara variabel satu dengan variabel yang lain". Teknik pengumpulan data melalui penyebaran Kuesioner. Hipotesisnya diuji dengan analisa Uji Validitas, Uji Reliabilitas, Uji T, Koefisien Korelasi dan Uji Regresi Linier Berganda seta Koefisien determinasi yaitu angka yang menyatakan besar kecilnya sumbangan yang diberikan variable independen terhadap variable dependen (Riduwan;2009:76).

\section{HASIL DAN PEMBAHASAN}

\section{A. Statistik Deskriptif}

Reliabilitas menunjukkan pada tingkat keandalan. Pengujian reliabelitas dengan teknik Cronbach Alpha mengacu pada kriteria bahwa nilai koefisien yang diperoleh harus lebih besar daripada 0,60. Hasil untuk uji reliabilitas terhadap instrumen data kuesioner dapat dilihat di bawah ini:

Tabel 1. Uji Reliabilitas

\begin{tabular}{|c|c|c|c|c|}
\hline No & Variabel & Koefisien & Kriteria & Ket \\
\hline 1 & Kompensasi & 0,729 & 0,6 & Reliabel \\
\hline 2 & Stres Kerja & 0,694 & 0,6 & Reliabel \\
\hline 3 & Turnover Intention & 0,747 & 0,6 & Reliabel \\
\hline
\end{tabular}

Hasil pengujian perhitungan pada tabel diatas menunjukan bahwa nilai koefisien untuk instrumen Kompensasi $\left(\mathrm{X}_{1}\right)$ sebesar 0,729. Nilai koefisien untuk instrumen Stres Kerja $\left(\mathrm{X}_{2}\right)$ sebesar 0,694 dan nilai koefisien untuk instrumen Turnover Intention (Y) sebesar 0,747. Hal ini menunjukan bahwa semua variabel memiliki nilai cronbach's alpha diatas 0,60 dinyatakan reliabel.

Berikut adalah resume tanggapan responden terhadap variabel Kompensasi, Stres kerja dan Turnover Intention.

Tabel 2. Resume Tanggapan Responden

\begin{tabular}{|l|l|c|l|}
\hline No. & Indikator & Skor & Kriteria \\
\hline 1. & Kompensasi & 375 & Sangat Baik \\
\hline 2. & Stres kerja & 367 & Tinggi \\
\hline 3. & Turnover Intention & 378 & Sangat Tinggi \\
\hline
\end{tabular}

Korelasi menunjukkan indikasi awal adanya hubungan antara variabel. Tabel 2. Terlihat bahwa nilai koefisien regresi untuk data besarnya pengaruh Kompensasi 
$\left(\mathrm{X}_{1}\right)$ dan Stres Kerja $\left(\mathrm{X}_{2}\right)$ sebagai variable bebas dan Turnover Intention sebagai variable terikat (Y) berikut hasil yang diperoleh :

Tabel 3. Uji Regresi Linier Berganda

\begin{tabular}{|c|l|c|}
\hline Variabel & \multicolumn{1}{|c|}{ Korelasi } & Turnover Intention \\
\hline Kompensasi & Pearson Correlation & 0,217 \\
\cline { 2 - 3 }$\left(\mathrm{X}_{1}\right)$ & Signifikansi & 0,002 \\
\hline Stres Kerja & Pearson Correlation & 0,096 \\
\cline { 2 - 3 }$\left(\mathrm{X}_{2}\right)$ & Signifikansi & 0,002 \\
\hline
\end{tabular}

Besar korelasi Kompensasi terhadap Turnover Intention sebesar 0,217 dengan tingkat signifikansi 0,002. Karena lebih besar dari kriteria umum yang digunakan yaitu $0,05(0,002>0,05)$, maka hal ini dapat disimpulkan bahwa Variabel Kompensasi memiliki korelasi positif dan signifikan terhadap Turnover Intention. Besar korelasi Variabel Stres Kerja terhadap Turnover Intention sebesar 0,096 dengan tingkat signifikansi 0,002. Karena lebih kecil dari kriteria umum yang digunakan yaitu $0,05(0,002<0,05)$, maka hal ini dapat disimpulkan bahwa Stres Kerja memiliki korelasi positif dan signifikan terhadap Turnover Intention.

Tabel 4. Korelasi antar Variabel

\begin{tabular}{|c|l|c|}
\hline Variabel & \multicolumn{1}{|c|}{ Korelasi } & Turnover Intention \\
\hline \multirow{2}{*}{ Kompensasi } & Pearson Correlation & 0,390 \\
\cline { 2 - 3 } & Signifikasi & 0,000 \\
\hline \multirow{2}{*}{ Stres Kerja } & Pearson Correlation & 0,396 \\
\cline { 2 - 3 } & Signifikasi & 0,000 \\
\hline
\end{tabular}

Koefisien korelasi Kompensasi diukur dengan variable Turnover Intention tingkat signifikansinya adalah 0,05 yang berarti menyatakan ada korelasi antara kedua variabel tersebut. Sedangkan untuk besar nilai koefisien korelasinya adalah 0,390 dengan tingkat signifikan 0,000. Karena lebih kecil dari kriteria umum yang digunakan yaitu $0,05(0,000<0,05)$. Hal ini dapat disimpulkan bahwa ada hubungan korelasi positif dan signifikan antara variabel Kompensasi dan Turnover Intention. Koefisien korelasi Stres Kerja diukur dengan variable Turnover Intention tingkat signifikansinya adalah 0,05 yang berarti menyatakan ada korelasi antara kedua variabel tersebut. Sedangkan untuk besar nilai koefisien korelasinya adalah 0,396 dengan tingkat signifikan 0,000. Karena lebih kecil dari kriteria umum yang 
digunakan yaitu $0,05(0,000<0,05)$. Hal ini dapat disimpulkan bahwa ada hubungan korelasi positif dan signifikan antara variabel Stres Kerja dan Turnover Intention.

\section{B. Pengujian Hipotesis}

Pengujian hipotesis dilakukan untuk menguji ada tidaknya hubungan positif atau negatif antara variabel independen yaitu Kompensasi dan Stres Kerja terhadap variabel dependen yaitu Turnover Intention. Untuk menguji hipotesis yang diajukan, uji statistik yang digunakan adalah uji t atau uji parsial dan koefisien determinasi. Hasil uji statistik $t$ dapat dilihat dari tabel di bawah ini.

Tabel 5. Uji $t$ atau Uji Parsial

\begin{tabular}{|l|c|c|c|c|c|}
\hline \multirow{2}{*}{ Variabel } & \multicolumn{2}{|c|}{$\begin{array}{c}\text { Unstandardized } \\
\text { Coefficient }\end{array}$} & $\begin{array}{c}\text { Standardized } \\
\text { Coefficient }\end{array}$ & \multirow{2}{*}{ t } & \multirow{2}{*}{ Sig } \\
\cline { 2 - 5 } & $\mathbf{B}$ & $\begin{array}{c}\text { Standar } \\
\text { Error }\end{array}$ & Beta & & \\
\hline Kompensasi & 0,217 & 0,068 & 0,310 & $-3,186$ & 0,002 \\
\hline Stres Kerja & 0,096 & 0,029 & 0,318 & 3,266 & 0,002 \\
\hline
\end{tabular}

Berdasarkan hasil perhitungan uji-t untuk variabel Kompensasi dalam tabel diatas nilai koefisiennya adalah sebesar 3,186 dan tingkat signifikasinya adalah 0,002. Karena $0,002<0,05$ maka $\mathrm{H}^{0}$ ditolak dan $\mathrm{H}^{1}$ diterima. Dengan demikian dapat disimpulkan bahwa Kompensasi memiliki pengaruh negatif dan signifikan terhadap Turnover Intention dan dapat dikonfirmasi.

Hasil perhitungan uji-t untuk variabel Stres Kerja dalam tabel diatas nilai koefisiennya adalah sebesar 3,266 dan tingkat signifikansinya adalah 0,002. Karena $0,002<0,05$ maka $\mathrm{H}^{0}$ ditolak dan $\mathrm{H}^{2}$ diterima. Dengan demikian dapat disimpulkan bahwa variabel Stres Kerja memiliki pengaruh positif dan signifikan terhadap Turnover Intention dan dapat dikonfirmasi.

Tabel.6. Uji Koefisien Determinasi

\begin{tabular}{|c|c|}
\hline $\mathbf{R}$ & R.Square \\
\hline $0,497^{2}$ & 0,247 \\
\hline
\end{tabular}


Besarnya koefisien determinasi sebagai berikut :

$$
\begin{gathered}
\mathrm{Kd}=\mathrm{R}^{2} \times 100 \% \\
=0,247 \times 100 \% \\
=24,7 \%
\end{gathered}
$$

Berdasarkan hasil pengujian koefisien determinasi dari Tabel 6 menyatakan bahwa perubahan-perubahan pada Turnover Intention dapat dijelaskan oleh variable Kompensasi dan Stres Kerja sebesar 24,7\%. Sisan sebesar 75,3\% dijelaskan oleh factor-faktor lain di luar kedua variable tersebut yang tidak dilibatkan dalam penelitian ini.

\section{SIMPULAN}

Kompensasi menurut tanggapan karyawan PT Kwangduk World Wide termasuk dalam kriteria "Sangat baik". Stres Kerja termasuk dalam kriteria "Tinggi", dan Turnover Intention termasuk dalam kriteria "Sangat tinggi". Sedangkan hasil dari penelitian adalah Kompensasi berpengaruh negatif dan signifikan terhadap Turnover Intention dan Stres Kerja berpengaruh positif dan signifikan terhadap Turnover Intention

Saran teoritis dan praktis, peneliti selanjutnya menggunakan variabel yang lebih luas yang mempengaruhi turnover intention atau keinginan keluar karyawan pada sebuah organisasi, sehingga diharapkan hasil penelitian yang akan datang akan lebih baik dari penelitian ini. Perusahaan harus kembali mengontrol job description atau pembagian tugas untuk karyawan jangan sampai karyawan lain mengerjakan tugas yang bukan pekerjaannya.

\section{DAFTAR PUSTAKA}

A.A. Anwar Prabu Mangkunegara. 2005, 2011. Manajemen Sumber Daya Manusia Perusahaan. Bandung : Rosda

Ardana, I Komang dkk. 2012. Manajemen Sumber Daya Manusia. Yogyakarta: Graha ilmu.

Asmara Hendra Komara dan Novi Erika (2017), Pengaruh Kompensasi, Promosi Jabatan dan Stress Kerja terhadap tingkat intensi turnover karyawan di PT. Dwiwira Putra Dinamika, Pekanbaru

Bibowo, Adi dan Masdupi, Erni (2015), Pengaruh Kepuasan Kerja, Kompensasi, dan Pengembangan Karir terhadap Turnover Intention pada Karyawan Bank Syariah 
Mandiri cabang Padang, Jurnal Riset Manajemen Bisnis dan Publik, Vol 3, No 3

Catur Widayati dan Yolanda Yunia (2016), Pengaruh Kompensasi dan Budaya Organisasi terhadap Turnover Intention, Jurnal Manajemen/Volume XX, No. 03

Erwin Paulus dan Heri Winoto Tj (2015), Pengaruh Kompensasi dan Kepuasan Kerja terhadap Turnover Intention Karyawan studi kasus pada PT. Multi Abadi Sejahtera, Jurnal ilmiah Manajemen Bisnis, VOL. 15, NO 2.

Handoko, T. Hani, 2000, 2008. Manajemen Personalia Sumber Daya Manusia, Edisi Kedua,Yogyakarta, Penerbit : BPFE

Hasibuan, Malayu S.P, 2003, 2008, 2012, 2013 Manajemen Sumber Daya Manusia, Edisi Revisi, Bumi Aksara, Jakarta.

Harnoto, 2002. Manajemen Sumber Daya Manusia, Edisi Kedua, PT. Prehallindo, Jakarta

Hermita. 2011. Pengaruh Stres Kerja Terhadap Kinerja Karyawan PT. Semen Tonasa (Persero) Pangkep. Skripsi FE Hasanuddin, Makasar.

Irabayuni, Sulastri (2012), Pengaruh Kompensasi, Kepuasan Kerja, dan Komitmen Organisasi terhadap Keinginan untuk Pindah Kerja pada PT SuryaSumber Daya Energi Surabaya

Johartono dan Widuri, Retnaningtyas (2013), Analisa Pengaruh Stres Kerja,Kepuasan Kerja, Budaya Organisasi, Dan Komitmen Organisasi terhadap Turnover Intention Karyawan Kantor Konsultan Pajak di Surabaya

K. Ayu Budiastiti Purnama Dewi dan I made Artha Wibawa (2016), Pengaruh Stress Kerja pada Turnover Intention yang dimediasi Kepuasan Kerja Agen AJB Bumi Putera 1912, Bali

Kadarisman, M. 2012. Manajemen kompensasi. Jakarta: Rajawali pers

Kuncoro, Mudrajat, (2007), Metode Kuantitatif, Teori dan Aplikasi untuk Bisnis dan Ekonomi, UPP STIM YKPN, Yogyakarta.

Mobley,W. H. 2011. Pergantian Karyawan: Sebab, Akibat dan Pengendaliannya. Alih Bahasa : Nurul Imam. Jakarta: PT Pustaka Binaman Pressindo.

Muhammad Khaidir (2016), Pengaruh Stres Kerja, Kompensasi dan Kepuasan Kerja terhadap Turnover Intention studi pada karyawan kontrak PT.Gagah Sataria manunggal Banjarmasin

Nugroho (2008). Keperawatan Gerontik. Buku Kedokteran EGC: Jakarta.

R. Joko Sugiharjo dan Irna Venewjila (2018), The Influence of Job Statisfication Job Stress and Compensation on Turnover Intention Employees, European Journal of Business and Management Vol.10, No.15

Richard L. Daft (2000). Manajemen. Jakarta: PT Gelora Aksara Pratama.

Robbins, P. Stephen. 2006, 2008, 2015. Perilaku Organisasi. Edisi Sepuluh. Diterjemahkan oleh: Drs. Benyamin Molan. Erlangga, Jakarta.

Samsudin, Sadili. 2006. Manajemen Sumber Daya Manusia. Bandung: Pustaka Setia

Septianto, Dwi. 2010. "Pengaruh Lingkungan Kerja dan Stres Kerja Terhadap Kinerja 
Karyawan Studi pada PT. Pataya Raya Semarang”. Skripsi. Semarang: Universitas Diponegoro.

Simamora, Henry. 1997, 2004, 2006. Manajemen Sumber daya Manusia. Yogyakarta: Sekolah Tinggi Ilmu Ekonomi YKPN.

Sugiono, 2007, 2013, 2012, 2017, "Metode Penelitian Kuantitatif, Kualitatif dan R\&D”. Bandung:Alfabeta

Syahronica, G., \& Ruhana, M. S. H. I. (2015). "Pengaruh Kepuasan Kerja dan Stres Kerja terhadap Turnover Intention(Studi Pada Karyawan Departemen Dunia Fantasi PT Pembangunan Jaya Ancol, Tbk)." Jurnal Administrasi Bisnis (JAB).Vol. 20. No. 1. pp. 1.

Umar, Husein.2003. Metodologi Penelitian: Aplikasi dalam Pemasaran. Jakarta: Gramedia Pustaka Utama

Veithzal Rivai, 2004, 2005, 2009, 2011 "Manajemen Sumber Daya Manusia Untuk Perusahaan" Cetakan Pertama, Jakarta, PT. Raja GrafindoPersada.

Wirawan, 2015. Evaluasi Kinerja Sumber Daya Manusia (Teori, Aplikasi, dan Penelitian). Jakarta: Salemba Empat.

Yuniarsih, Tjutju. dan Suwatno. (2011). Manajemen Sumber Daya Manusia. Bandung : Alfabeta

Yuliana Ayu Wulansari, Teman Koesmoro, Marliana Junaedi (2017), Pengaruh Keadilan Prosedural dan Stres Kerja terhadap Turnover Intention dengan Komitmen Organisasional sebagai Variabel Mediasi pada PT. PJB Services, Surabaya 